\title{
FAILURE OF AN INTER-KOREAN POLICY: THE CASE OF TRUSTPOLITIK
}

\author{
Geetha Govindasamy, Erwin Tan \& Park Chang Kyoo
}

\begin{abstract}
Park Guen Hye's Trustpolitik was a bold initiative that sought to improve relations with North Korea. It was a policy departure from the flawed strategies of her predecessors who were either too lenient or hardline towards Pyongyang. However, the fact that the trust-based policy was a conditional form of engagement meant that the North Korean leadership had little incentive in supporting the policy. Given that Seoul and Washington wanted Pyongyang to denuclearize as a sine qua non for reciprocal concessions, the Trustpolitik failed to induce any significant progress in inter-Korean relations. Kim Jong Un's adoption of the Byungjin policy, which envisioned parallel undertaking of the North Korean nuclear program alongside economic reforms, pointed to the ominous scenario that he had no interest in accommodating Park's Trustpolitik. Further, South Korean domestic response to Truspolitik was also far from positive, especially when Park's conservative Saenuri Party failed to obtain a majority in the 2016 parliamentary elections and after a legislative impeachment vote in 2017 which removed Park Guen Hye from the Blue House.
\end{abstract}

Keywords: Trustpolitik, Park Guen Hye, denuclearization, impeachment, Saenuri Party

\section{Introduction}

Developments on the Korean Peninsula since 2012 posed significant challenges for Republic of Korea (ROK) under President Park Geun Hye in addressing the increasingly erratic conduct of the Pyongyang regime since the succession of Kim Jong Un as Supreme Leader of North Korea in 2011. Since his succession, the new North Korean leader ordered a multitude of missile and nuclear tests in 2013 and 2016. The earlier set of actions were accompanied by a temporary closure of the Kaesong Industrial Complex (KIC); in response to North Korea's provocations, Park indefinitely suspended any further South Korean involvement in the KIC. Given that these developments were accompanied by an unprecedented level of rhetorical vitriol as well as personal insults at Park, there were fears that the resulting tensions marked a danger of a second Korean War.

Set against these tensions, there were widespread discourse on the efficacy of Park Geun Hye's adoption of a trust-based policy towards North Korea, known as Trustpolitik. Although the latter had some accomplishments, such as the facilitation of inter-Korean family reunions in February 2014 and the reopening of the KIC in August 2013, the overall pattern of inter-Korean relations offered little ground for optimism. North Korea's continued missile and nuclear tests and Kim Jong Un's pointed refusal to offer any concessions on these issues posed a continuing challenge to inter-Korean relations. Rather, Kim Jong Un's adoption of the Byungjin policy, envisioning parallel undertaking of the North Korean nuclear program alongside economic reform, pointed to the ominous conclusion that the new leader had no interest in accommodating Park's Trustpolitik.

We outline our analysis in three parts. First, it will be necessary to examine the place of Park Geun Hye's Trustpolitik in the evolution of Seoul's North Korea policy. Second, given that Trustpolitik has failed to elicit a more conciliatory response from the North, we will examine the factors that have complicated attempts at improving inter-Korean relations. These include domestic difficulties within the ROK, the US prioritisation of denuclearisation of North Korea, Kim Jong Un's adoption of a more provocative posture, and the attempts by the ROK in garnering international support through the Northeast Asia Peace and Cooperation Initiative 
(NAPCI). This article then concludes why inter-Korean relations for the remainder of Park Geun Hye's tenure as President failed.

\section{Park Geun Hye's Policy towards the Korean Peninsula}

Early on, Park Geun Hye adopted a strategy of Trustpolitik that sought a balanced policy response to the challenges posed by Pyongyang. By 2011, Park had written an article in Foreign Affairs, hinting at her willingness to engage the DPRK based on a Trustpolitik. In spite of the childhood trauma she experienced with the death of her mother at the hands of a North Korean agent in 1974, Park wrote of her desire for 'enduring peace' on the Korean Peninsula, but of how efforts at 'genuine reconciliation' had failed to evoke trust between Seoul and Pyongyang. Equally important, Park urged the formation of a 'cooperative security regime ... [in which] economic and political cooperation can overcome military and security cooperation'.1 In calling for a security regime, Park's article underpinned her recognition that a long-term diplomatic vehicle for building long-term trust offered the best prospect of mitigating the possibility of conflict on the Korean Peninsula.

In outlining her vision of Trustpolitik, Park called for the adoption of 'two coexisting strands: first, North Korea must keep its agreements made with South Korea and the international community to establish a minimum level of trust, and second, there must be assured consequences for actions that breach the peace'.2 Hence, Park's vision for Trustpolitik was buttressed by an 'alignment' policy that envisaged 'a tough line against North Korea sometimes and flexible policy open to negotiations at other times.' Thus, even whilst underlining her refusal to further tolerate North Korea's provocative behaviour, Park also advocated her willingness to 'offer Pyongyang a new beginning'.3

Taken together, Park's Trustpolitik attempted to underline these key principles as starting points that Pyongyang was expected to abide by balance between the positions of precious ROK Presidencies, which were heavily criticised for lacking nuance in addressing North Korea. In this regard, it is necessary to emphasize that Park's Trustpolitik was a response to the flawed strategies of her predecessors. Thus, for instance, Park noted that the efforts by Kim Dae Jung and Roh Moo Hyun in accommodating Pyongyang had failed to bring about fundamental change in the DPRK's aggressiveness; conversely, Park was equally critical of the fact that Lee Myung Bak's coercive diplomacy had also failed to influence North Korea. From 1998 to 2007, Presidents Kim Dae Jung and Roh Moo Hyun had sought to increase inter-Korean trade and humanitarian aid to the North, in spite of the provocative 1998 and 2006 missile and nuclear tests. Conversely, Lee Myung Bak, who succeeded to the Presidency in 2008, adopted the opposite extreme.

Citing the failure of his predecessors to bring an end to North Korea's missile and nuclear ambitions, Lee adopted a more hardline posture toward North Korea and stronger security relations with Washington. Seen in this light, Pyongyang's 2009 missile and nuclear tests, along with the sinking of the ROK warship Cheonan in 2010 (leading to 46 casualties), were arguably intended by Pyongyang to communicate hostility against the Lee Myung-Bak Administration. Notwithstanding Pyongyang's anger over Lee Myung Bak's repudiation of engagement with North Korea, the South Korean President retaliated over the sinking of the Cheonan with the 'May 24 Measures', a set of harsh punitive sanctions. In essence it prohibited North Korean ships in South Korean waters, froze government level interactions, further expansion of inter-Korean economic cooperation, investment relations, aid to Pyongyang, and people-to-people contact. Such measures in turn led

1 Park G. H, “A New Kind of Korea,” Foreign Affairs, September/October, 2011,

http://www.foreignaffairs.com/articles/68136/park-geun-hye/a-new-kind-of-korea. Accessed 2 December 2012.

2 Park G.H, "A New Kind of Korea."

3 Park G.H, "A New Kind of Korea." 
to a further round of the escalating vicious circle in inter-Korean hostility, as reflected in the North Korean bombardment of Yeongpyong Island (causing 4 fatalities) in November 2010, and an increasing number of missile and nuclear tests since 2012.4 Given the extent of South Korean outrage over the casualties sustained in the Cheonan sinking and the Yeongpyong Island bombardment, punitive measures against the DPRK continued to find much support amongst hardline conservatives in South Korea, despite calls from opposition lawmakers to lift these sanctions.

Set against this backdrop, Park Geun Hye's Trustpolitik evidently sought to balance between the hardline coercive diplomacy adopted by Lee Myung Bak, whilst simultaneously avoiding the series of one - sided concessions by Kim Dae Jung and Roh Moo Hyun. Given the importance of trust as the basis for any meaningful relationship between Seoul and Pyongyang, Park's emphasis on 'enforcing trust' reflected a posture of seeking to build a more cooperative interKorean relationship that simultaneously affirmed a posture of firmness against Pyongyang's past provocations. By affirming Seoul's peaceful intentions, Park clearly made an effort to address Pyongyang's security fears. At the same time, by affirming her willingness to retaliate against any further North Korean transgressions, she also underlined Seoul's willingness to shift toward a more coercive posture if necessary.

On multiple occasions in the past, North Korea repeatedly justified its nuclear and missile programs for its own survival: in response, Park Geun Hye emphasised that Pyongyang is neither special nor immune to the rule of international law, and that North Korea should abide by universally shared norms of conduct. Furthermore, Park emphasised that whilst her administration is prepared to continue the process of engagement with the North, continued aid to the DPRK and investment in the KIC should not be seen by Pyongyang as a series of one-sided concessions. Park thus underlined the need for North Korea to undertake reciprocal actions that indicate Pyongyang's acknowledgement of Seoul's interests. In addition, North Korea's track record of unpredictable behaviour, brinkmanship diplomacy and aggressive conduct needs little elaboration. In response, Park's continued South Korean engagement with the North was premised on Pyongyang putting an end to the use of such provocative behaviour towards Seoul.

Park's vision of Trustpolitik envisioned four broad policies that combined deterrence alongside reassurance toward the DPRK. First, in light of North Korea's track record of aggressive behaviour, Trustpolitik was premised on the maintenance of a strong posture of security to affirm the credibility of South Korean deterrence against Pyongyang's brinkmanship diplomacy. Second, given that the past decades diplomacy with Pyongyang had seen constant DPRK reneging on past agreements, Trustpolitik also affirmed Seoul's willingness to take a firm line in holding North Korea accountable in upholding its existing agreements, including, crucially, Pyongyang's commitment to complete nuclear disarmament under the Joint Statement of September 2005. Third, reflecting the need for flexibility, Park's vision for Trustpolitik also included a process of diplomatic engagement to socialise Pyongyang into becoming a responsible member of international society. Finally, implementation of Trustpolitik was also based on securing a broad base of support and trust on the part of the South Korean population, along with close cooperation with international society through the implementation of NAPCI in late 2013. Seoul's unveiling of NAPCI was reflective of the ROK's growing self-consciousness of its increasingly prominent role and economic clout on the world stage. Yet, given the concurrent uncertainty and tensions arising from Seoul's neighbour, it was apparent that Park Geun Hye was intent on exercising greater influence as a middle-ranking power in the Asia Pacific region, whilst simultaneously safeguarding South Korean security interests. NAPCI's

4 Kelly, R, "Yeonpyeong Shelling Summation (1): Context and Causes in hindsight," 2010, http://asiansecurityblog.wordpress.com/2010/12/13/yeonpyeong-shelling-summation-1-context-and-causesinhindsight/. Accessed 17 June 2016. 
vision thus intended a 'culture of dialogue and cooperation' in Northeast Asia as part of the process of easing inter-Korean tensions.

In her New Year's Address in January 2014, President Park referred to the prospect of Korean unification as a Daebak (jackpot). It was apparent that Park Geun Hye was inspired by the German experience of reunification following the end of the Cold War. On 28 March 2014, in the city of Dresden in the former East Germany, Park proposed the Dresden Initiative, incorporating a range of humanitarian, economic and other dimensions to assist in the gradual rehabilitation of North Korea. This envisaged humanitarian assistance, collaborative economic projects between the two Koreas, Russia and China, and the setting up of a 'World Eco Peace Park' along the Korean Peninsula De-Militarized Zone as a corridor for reconciliation between the two Koreas. There was no coincidence in Park's decision to visit Dresden, which was devastated by bombing during World War Two and came under the control of the Communist East German state. Yet, the subsequent rebuilding of Dresden as a centre of culture and industry enabled the city to emerge as the fastest economically growing region in the former East Germany, hence a significant symbol of peace and reconciliation underpinning a unified nationstate.

Furthermore, in envisioning a normalisation of inter-Korean relations, it was also apparent that Park was willing to follow up on the process of engagement that had been initiated by Kim Dae Jung, with a call for the resumption of the reunion of families divided by the Korean War and cooperation in investigating the status of South Korean nationals abducted by Pyongyang, and joint teams to locate the remains of soldiers from the Korean War. Moreover, Park indicated willingness to go beyond the process of engagement that had been initiated by Kim Dae Jung and Roh Moo Hyun. Whilst the latter governments had placed a central role for South Korea in channelling investment into the KIC, Park called for the latter to be transformed into a global center for international investment from other countries. Furthermore, Park's support for assistance in developing Pyongyang's ability to exploit its mineral resources was particularly notable, given that North Korea's natural resources is estimated to be worth US\$6 trillion - 150 times the country's entire GDP, yet largely untapped due to the country's decrepit infrastructure.5 Equally significant was Park Geun Hye's enthusiasm for the transformation of the De-Militarised Zone (DMZ) into a 'peace park' or nature reserve; given that the DMZ had long been seen as a symbol of the division of the Korean Peninsula, such a form of ecological détente in inter-Korean relations would have helped to symbolise reconciliation between Seoul and Pyongyang.6 Despite these optimistic initiatives, Trustpolitik failed to elicit any significant improvement in inter-Korean relations due to North Korea's continued provocative actions as well as developments in domestic politics in South Korea. In this sense, one underlying weakness of Trustpolitik stemmed from the mere fact that Park herself failed to clearly articulate how she planned to accomplish the myriad of ideas that she had outlined. The conditional nature of engagement, in linking any further ROK concessions to Pyongyang to the denuclearisation of North Korea, was clearly a non-starter for Kim Jong Un.

\section{The Main Obstacles to Trustpolitik}

\section{Domestic Factors in South Korea}

Further complicating the prospects for a coherent ROK policy towards North Korea was reflected in the increased inter-party wrangling within South Korea. Following the February 2016 North

5Bruce S.T, "North Korea's Six Trillion Dollar Question,” The Diplomat, 30 August, 2012.

http://thediplomat.com/2012/08/30/north-koreas-six-trillion-dollar-question/. Accessed 7 October 2013.

6 "Opinion Divided Over DMZ Peace Park," Korea Herald, 1 September, 2013,

http://www.koreaherald.com/view.php?ud=20130901000329. Accessed 1 October 2014. 
Korean nuclear test, Park Geun Hye decisively turned her back on further engagement with Pyongyang, instead aiming to impose tighter sanctions in order to bring about the collapse of the North Korean regime. Yet, such a position was difficult to implement, given the extent of the conservative Saenuri Party's electoral defeat during the National Assembly elections in April 2016. This shift to a domestic liberal caucus within the ROK's legislative assembly portended the prospect of further stalemate. ROK liberals placed in a stronger position began criticizing Trustpolitik's emphasis on conditionality. Minjoo Party figures like Moon Jae-in remained committed to proactive engagement with North Korea through negotiations, rather than sanctions. As such, Moon pressed for economic engagement with the North and the lifting of the May 24 sanctions on Pyongyang, even as the process of North Korean denuclearisation remained stalled. Similarly, Ahn Cheol-soo from the People's Party marked the 15th anniversary of the first InterKorean Presidential Summit by calling for economic and political rapprochement with Pyongyang.7 This liberal shift was, however, complicated by the fact that South Korean public opinion remained deeply hostile towards North Korea over Pyongyang's increasingly provocative actions since 2009. As such, having already lost the National Assembly elections, Park refused to consider a change in policy for fear of isolating her remaining conservative domestic allies.8

Following the February 2016 North Korean nuclear test, Gallup Korea indicated that more than half of the South Korean public favoured closing Kaesong and suspending aid to the North.9 If anything, the increasing demographic shift in South Korea towards a younger generation with no living memory of family members separated by the Korean War meant that more and more young Koreans had little enthusiasm for seeking unification with the North. Rather, there was widespread realisation that Korean unification would result either from an armed conflict or internal collapse of the DPRK, both of which were scenarios which would impose a significant financial and material burden on the younger generation. Although older South Koreans with surviving relatives in the North and memories of the Korean War continue to support unification, younger South Koreans (especially in their 20s) had less enthusiasm for such an enterprise. As a result of the generational divide and North Korea's provocative behaviour, most younger South Koreans viewed the North more distantly. Furthermore, most South Koreans in their 20s did not recognise the northerners as having the same ethnic identity as them. The reality was that most younger South Koreans were increasingly preoccupied with more immediate issues such as job security, family life and the cost of living, and also they recognised that reunification with the North would result in their generation having to subsidise the economic rehabilitation of North Korea.10

Further complicating unification was the fact that the function of Park's Presidential Unification Preparation Committee also seemed to be unclear, as it overlapped with the existing National Unification Advisory Council (NUAC) and Ministry of Unification. The Committee's main role was to prepare for unification with the North; yet, the NUAC, established under Article 92 of the Constitution, had similar functions that included gathering information and planning for

7 J. Delury, “Listening to Korea’s Liberals," 38 North, 20 April 2016,http://38north.org/2016/04/jdelury042016/. Accessed 15 May 2016.

${ }_{8}$ Choe S.H, “After South Korea Spurns Park Geun-hye, She May Press Agenda Abroad,” New York Times, 15 April 2016, http://www.nytimes.com/2016/04/15/world/asia/south-korea-elections-park-geun-hye.html?_r=0. Accessed 8 June 2016.

9 J. Van Oosterhout, "Discarding Kaesong: Reviving the Cold War on the Korean Peninsula?", Foreign Policy Journal, 24 February 2016, http://www.foreignpolicyjournal.com/2016/02/24/discarding-kaesong-reviving-thecold-war-on-the-korean-peninsula/, accessed 11 May 2016.

${ }_{10}$ Gus Taylor, "Young South Koreans fear unification with North would create economic burden", Washington Times, 10 April 2013, available at: http://www.washingtontimes.com/news/2013/apr/10/young-south-koreansfear-unification-with-north-wo/?page=all, accessed 28 March 2015; S. Denny, "The Generation Gap on Korean Unification," The Diplomat, 29 January, 2015, http://thediplomat.com/2015/01/the-generation-gap-on-koreanunification/. Accessed 28 March 2015. 
unification.11 At the same time, the Ministry of Unification, which acts as an intermediary with Pyongyang, was also involved in unification matters through dialogue and policy implementation. Given that these functions were similar to the Unification Committee's role, it was unclear why Park Geun Hye embarked on adding another level of governmental complexity. Moreover, Professor Yang Moo Jin of the University of North Korean Studies highlighted the lack of clearly identified objectives of the Unification Committee since

the 'national community' approach to unification was an official plan that included three stages: first reconciliation and cooperation, then an inter-Korean federation, and finally unification ... I'm not sure it makes sense to talk about preparing for stage three when stage one isn't even working. 12

The lack of a clearly identifiable agenda for the Presidential Committee for Unification Preparation was similarly reflected in March 2015, when its Vice-Chairman, Chung Chong-wook, inadvertently alluded to contingency planning for the possibility of unification of the Korean Peninsula through absorption. In light of the existing suspicions in inter-Korean relations and the ROK's prosperity over its northern neighbour, it was hardly surprising that the North's leadership condemned the committee's role in unification matters as being more in tune with regime confrontation rather than 'trust' or 'dialogue' If anything, critics claimed that, by devoting such extensive efforts to a post-unification scenario, the subtext is that Park Geun Hye was focusing on unification by absorption, rather than managing inter-Korean relations. 13

\section{US Preoccupation with Nuclear Proliferation}

A further obstacle to achieving a rapprochement in inter-Korean relations was from the Obama Administration's prioritisation of the denuclearisation of North Korea. Any improvement in inter-Korean relations depended greatly on Washington's relations with both Seoul and Pyongyang. The simultaneous electoral wins of Obama in the US and Park Geun Hye in the ROK in 2012 initially offered opportunities for Washington and Seoul to coordinate a sustained process of diplomatic and security engagement with Pyongyang, but these did not materialize due to domestic constraints in the US as well as increased North Korean provocations.

As Senator, Obama had made an effort to enter into the fears of the North Korean leadership. Speaking at the Senate Committee on Foreign Relations in 2005, Obama had noted that, through its hard-line posture and 'strong rhetoric [the Bush Administration] may have boxed itself in ... North Korea is still going to be on the list of evil empires, and causing the North Koreans to be wary of changing their behaviour.' 14 This was followed by numerous statements during his 2008 Presidential campaign, when he repeatedly outlined his intention to

11 Seok Jin-hwan, "Park's unification committee's first meeting little more than hot air," The Hankyoreh, 8 August 2014, available at: http://www.hani.co.kr/arti/english_edition/e_northkorea/650384.html. Accessed 28 March 2014

12 Seok Jin-hwan, “'Park's unification committee's first meeting little more than hot air."

$13 \mathrm{Kim}, \mathrm{S}$, “Seoul under fire for remarks on 'absorption' of North Korea," NKNews. 16 March, 2015, http://www.nknews.org/2015/03/seoul-under-fire-for-remarks-on-absorption-of-north-korea/. Accessed 31 March 2015.

14 B. Obama, "North Korea: An Update on Six Party Talks and Matters Related to the Resolution of the North Korean Nuclear Crisis," Hearing Before the Committee on Foreign Relations, United States Senate, Washington: United States Government Printing Office, 2015. 
hold dialogue with erstwhile US foes such as North Korea without the rigid preconditions that had been imposed by Bush.15

Such expectations were not borne out in the aftermath of Obama's election victory in 2008. Within weeks of Obama's inauguration, North Korea abducted two American journalists on the border with China and conducted further nuclear and missile tests. Such a pattern of provocative North Korean actions ruined whatever appetite that the new White House might have had for following through with diplomatic engagement with Pyongyang. If anything, Obama's ambitious policy agenda envisaged national economic recovery, domestic welfare reform as well as winding down US military operations in the Middle East, whilst simultaneously fending off Republican accusations of weakness on national security. Under such circumstances, Pyongyang's general track record of provocative behavior further contributed to the commonly-held image of North Korea as the archetype untrustworthy 'rogue state' led by irrational war-mongers, and thus a convenient whipping boy whenever the Obama Administration needed to burnish its national security credentials.

Such an approach was further accentuated with Obama's appointment of former First Lady Hillary Clinton to the position of Secretary of State. As her husband, President Bill Clinton, was held office during the signing of the Agreed Framework of 1994, the Clinton name has long been associated by Republican hardliners as being synonymous with a willingness to compromise on US national security. Given Mrs Clinton's own aspirations to high office, the necessity of her underlining a willingness to adopt a conservative foreign policy posture has been demonstrated in what she referred to as 'strategic patience in close consultations with our six party allies.' 16 Such an innocuous-sounding position belied a rather more cynical set of assumptions on the part of the Obama White House; in light of the Lee Myung Bak administration's repudiation of engagement with Pyongyang, Clinton implied US acquiescence to the overall position of coercive diplomacy that had been the hallmark of the Bush Administration.

By insisting on Pyongyang making the first move as a precondition for US concessions to the DPRK, it was hardly surprising that the North Korean leadership responded with a posture of defiance. In leading to what Pyongyang perceived to be a continuation of a hostile US-ROK alignment, the North Koreans retaliated in 2010 with the sinking of the ROK corvette Cheonan and the bombardment of Yeongpyong Island.

The overall pattern of US-ROK coercive diplomacy against North Korea, disguised as 'strategic patience', resulted in further DPRK actions such as continued missile and nuclear tests in 2012-13 and 2016, and the planting of landmines on the South Korean side of the DMZ.17 Even after the ROK's Presidential transition to Park Geun Hye in February 2013, the North Korean reputation for irrationality and war-mongering behaviour continued to make it a convenient 'poster boy' for a rogue state that the Obama Administration could use to demonstrate firmness in foreign and security policy, yet one whose conventional military strength is so weak that such coercive diplomacy can be undertaken without risking a regional conflict.

This is not to say that the Obama Administration chose to rule out the possibility of a rapprochement with North Korea, rather, it was apparent that, in light of the backdrop of

15 "Obama offers change Kim Jong-Il can believe in,” World Tribune, 2008, http://www.worldtribune.com/worldtribune/WTARC/2008/ea_nkorea0256_06_19.asp. Accessed 10 August 2008.

16 S. Snyder, "U.S. Policy Toward North Korea," Council on Foreign Relations, January 2013, http://www.cfr.org/north-korea/us-policy-toward-north-korea/p29962, accessed 8 June 2016. 17 Choe S. H, "South Korea Accuses the North After Land Mines Maim Two Soldiers in DMZ," New York Times, 11 August 2015, http://www.nytimes.com/2015/08/11/world/asia/north-korea-placed-mines-thatmaimed-2-south-korean-soldiers-at-dmz-seoul-says.html. Accessed 10 May 2016. 
hostility and suspicion between the US and North Korea, the Obama Administration chose to significantly raise the bar for Pyongyang to pass, before any effort at serious engagement with North Korea could be initiated. Such dynamics were particularly salient for the year 2016 and beyond. Although constitutionally barred from seeking re-election, Obama was aware that his legacy had a potentially decisive level of influence on the outcome of the 2016 US Presidential elections. Such stakes were all the higher given the deeply polarising nature of both the Democratic and Republican candidates.

Thus, for instance, in February 2016, following Pyongyang's alleged test of a hydrogen bomb, the DPRK proffered the possibility of a peace treaty with the US to formally end the Korean War as the starting point for negotiating the nuclear disarmament of North Korea. Such a position was a non-starter for the Obama Administration, given the widelyheld perception of the North Korean leadership as untrustworthy; as noted by State Department Spokesman John Kirby, '(W)e carefully considered the [North Korean] proposal, and made clear that denuclearization had to be part of any such discussion.' 18 If anything, the concurrent tensions between the US and China over the South and East China Seas gave the US growing reasons to retain sizeable military assets in the East Asian region. At the same time, given that explicit reference to China as a rationale for such a US military presence would provoke China, the Obama Administration found it more convenient to hold North Korea up as a less controversial justification for the continued US military presence in the region. In short, given that both Washington and Pyongyang took to demanding preconditions that could be fulfilled by the other side as a sine qua non for reciprocal concessions, it was difficult to imagine either side taking the first step in moving away from the stalemate.

Such dynamics further were complicated by Seoul's opening of discussions concerning the deployment of the US Terminal High Altitude Area Defense (THAAD) to the Korean Peninsula. THAAD was conceived by the US military as a missile defense system designed to intercept incoming cruise missiles and thus protect key logistics nodes such as airports and ports to facilitate the deployment of US combat reinforcements to a given theater of operations.19 The deployment of such a capability to the Korean Peninsula was a logical response to the prospect of a North Korean nuclear missile arsenal that would presumably be used to interdict key ROK airbases and ports to block the deployment of US reinforcements in the event of war. In light of North Korea's claim to have successfully tested a submarinelaunched missile (which would grant Pyongyang second-strike nuclear capability), eventually South Korea agreed to the THAAD deployment. This in turn further complicated the process of engaging Pyongyang. Since THAAD could also be used to facilitate the deployment of sufficient US combat troops to invade North Korea, the existing paranoia of the North Korean leadership exacerbated.20 Furthermore, China and Russia had their own reservations over the US deployment of THAAD to the Korean Peninsula. Beijing and Moscow were experiencing tensions in their respective relations with Washington due to crises in the South China Sea and Ukraine. Under such circumstances, the deployment of THAAD to Northeast Asia conferred on the US military a strongly enhanced ability to geo-strategically encircle Chinese and Russian power projection capabilities. Moreover, Chinese and Russian opposition to THAAD gave both governments increased incentive to refuse cooperation with

18 S. Leon, “The Off-Ramp with North Korea,” Nautilus Institute, 3 March 2016,

http://nautilus.org/napsnet/napsnet-policy-forum/the-off-ramp-with-north-korea/, accessed 10 May 2016.

19 M. Elleman, M. J. Zagurek Jr., "THAAD: What It Can and Can’t Do,” 38 North. 10 March, 2016, http://38north.org/2016/03/thaad031016/. Accessed 8 June 2016.

20 A. Mehta, "Carter: THAAD in Korea 'Going to Happen," Defense News, 8 April, 2016, http://www.defensenews.com/story/defense/international/asia-pacific/2016/04/08/carter-thaad-korea-goinghappen/82803470/. Accessed 10 May 2016. 
whatever remaining perspectives in South Korea that continued to support engagement with the North.

\section{North Korea's Response}

The succession of Kim Jong Un as the next leader of North Korea since 2009 may shed some light into the nature of the governing ideology of the DPRK. The fall from favour of Kim Jong Il's older two sons over their lack of credibility in adhering to the DPRK's political ideology arguably reflects Kim Jong Il's preference for an orthodox leadership. In contrast to this, the available media information on Kim Jong Un paints a portrait of a leader who closely parallels the DPRK's founding father, Kim Il Sung. Whilst the overseas education in Switzerland of Kim Jong Un had led to initial hopes of the international community that the new North Korean leader would be willing to embrace a more liberal foreign policy and economic reform, it is apparent that the younger Kim sees no contradiction between elements of a personal Western lifestyle alongside the continuation of North Korea's Communist Juche political ideology.

This combination of influences provides a plausible explanation for the pattern of North Korean actions since December 2011. Although the Kim Jong Un leadership is doubtless aware of the pressing economic challenges faced by the country, it is obvious that any move towards economic reform will be tightly controlled. By extension, it was also apparent that the DPRK has little intention of making concessions to Seoul and Washington on its missile and nuclear programs between 2013 and 2017. Thus, for instance, a resumption of talks between the US and North Korea led to the signing of the 'Leap Year Agreement' of February 29, 2012, under which the North Koreans agreed to end missile and nuclear testing as a quid pro quo for economic and humanitarian aid from the US. Yet, the ink was barely dry on the 'Leap Year Agreement' when the DPRK announced its plans to undertake yet another test of the Kwangmyongsong rocket. Given the dual-use nature of rocket technology, this was seen as a cover for testing an Intercontinental Ballistic Missile capable of hitting the US. Although the April 2012 missile test failed, this was followed by another Kwangmyongsong test in December the same year that succeeded in reaching orbit (thereby reflecting North Korean progress in seeking an operational long-range missile). The period since the beginning of 2013 saw the testing of a nuclear device in February, a massive increase in military exercises that explicitly threatened against the ROK and US, as well as temporary closure of the Kaesong Industrial Complex in April 2013. The latter action was seen as particularly shocking, given the extent of the financial lifeline to the Pyongyang regime - one estimate is that the Kaesong Industrial earned the Pyongyang regime the equivalent of US $\$ 90$ million annually.21 Given the near-destitute state of the North Korean economy, Pyongyang's willingness to forego such a significant portion of its income can be seen as a sign that Kim Jong Un was prepared to escalate confrontation with the ROK and US. Such a perspective is further supported by North Korea's acceptance of the ROK imposing a permanent closure of the KIC in February 2016.

Such developments suggested that the North Korean leadership was actively embarking on a Byungjin policy (which translates as 'parallel track') that attempted to achieve economic development of the DPRK, whilst still allowing Pyongyang to retain its nuclear weapons program. Such a strategy was not surprising, in light of evidence that suggests increasing factionalism within Pyongyang between pro-reform moderates who prioritise economic development, and military hardliners intent on retaining a nuclear arsenal as the DPRK's ultimate security

21 "Pyongyang Threatens to End Venture," Wall Street Journal, 8 April, 2013, http://online.wsj.com/article/SB10001424127887323550604578410010892971052.html. Accessed 7 October 2013. 
guarantee. 22 Such factionalism may have characterised the Seventh Congress of the Korean Worker's Party in May 2016. It was apparent that the Congress was aimed more at consolidating Kim Jong Un's power succession, rather than on addressing the country's pressing challenges. Aside from the usual militaristic rhetoric affirming the DPRK's nuclear ambitions, it was notable that there was little mention of any move towards engaging the US or South Korea in building a peace regime on the Korean Peninsula.

Such a trend continued, in light of North Korea's perception of South Korean and US hostility; this was further driven home by the increasingly explicit nature of US-ROK military exercises in 2016. Between March and April 2016, the allies conducted the Foal Eagle and Key Resolve military exercises, deemed to be the largest of such exercises in recent memory. Involving an unprecedented 317,000 US and ROK military personnel, military sources also indicated that the updated OPLAN 5015 envisaged an offensively-oriented military posture, including precision attacks on the North Korean leadership as well as pre-emptive military operations to neutralise the North Korean nuclear missile arsenal.23 Whilst US ROK chestthumping was hardly surprising given Pyongyang's own aggressive behaviour, such explicit imposition of insecurity against Kim Jong Un could hardly be expected to inspire confidence to improve inter-Korean relations. Rather, the track record of coercion against North Korea indicated that the DPRK has generally retaliated to such provocations with increased defiance and belligerence.

In addition, the extent of antagonism, suspicion and distrust in inter-Korean relations became deeply internalised (all the more so in the aftermath of the Cheonan sinking and the Yeongpyong Island bombardment in 2010, and the missile and nuclear tests in 2012, 2013 and 2016). Under such circumstances, it was difficult to imagine which side - Seoul or Pyongyang would be willing to take the first concrete steps in moving beyond the rhetoric of Trustpolitik or Byungjin. If anything, by outlining her vision in Dresden in the former East Germany in April 2014, Park Geun Hye's intention to support redevelopment of North Korea was taken by Pyongyang as evidence that the ROK sought unification through absorption. Given that the integration of Dresden into the Federal Republic of Germany marked part of the collapse of the communist East German regime, it was hardly surprising that the DPRK interpreted Park's position has seeking the collapse of the North Korean regime. In reality, any improvement in inter-Korean relations would only take place if there was a lifting of the May 24 Measures which had a dual impact on inter-Korean relations - firstly, its very existence hampered Park Geun Hye's vision of aiding and improving North Korea's economy and infrastructure as part of the South Korean leader's Dresden Doctrine; secondly, from the North Korean point of view, the existence of the May 24 Measures converged on Pyongyang's existing distrust of the South, leading to an impasse in inter-Korean relations.

\section{The International Response to Trustpolitik}

In seeking to foster peace and cooperation in inter-Korean relations, Park Geun Hye had also introduced a new multilateral concept, the NAPCI, which aimed to build trust first on nontraditional regional issues such as the environment, nuclear safety and energy security, and then military security. In so doing, it was apparent that Park Geun Hye sought to introduce a new,

22 “N. Korea Warns against Factionalism in Ruling Party,” Yonhap News, 26 February, 2014, http://english.yonhapnews.co.kr/northkorea/2014/02/26/73/0401000000AEN20140226002100315F.html. Accessed 14 March 2015.

23 "S. Korea, U.S. begin largest-ever anti-North military drills," Yonhap News, 7 March 2016, http://english.yonhapnews.co.kr/news/2016/03/07/0200000000AEN20160307007151315.html, accessed 10 June 2016. 
multilateral framework for international relations in Northeast Asia that would aid the interKorean peace process over the long-run.

Yet, the feasibility of NAPCI itself was questionable, for several reasons. Firstly, the US itself had proven to be lukewarm in its support for the ROK initiative, apparently due to Washington's concern that such an arrangement would undermine the strength of the US alliances and influence with the ROK and Japan. This was a particularly disturbing scenario for the US, given that a rising China would have more leverage on Asia Pacific matters.24

Conversely, the fact that the ROK was only a middle-rank power surrounded by larger neighbours with conflicting interests, it was apparent that Washington was unsure of the extent to which the ROK could successfully achieve its vision for NAPCI.25 Furthermore, it should be noted that NAPCI envisaged a multilateral regional framework not unlike the stalled Six Party Talks. Given that the latter had failed to bring about the denuclearisation of the Korean Peninsula, it was questionable as to how effective NAPCI would be in enhancing Park Geun Hye's Trustpolitik. If anything, Pyongyang probably came to view the multilateral format of the Six Party Talks as being aimed to maximise pressure on North Korea. Under such circumstances, the North Korean leadership viewed NAPCI as another channel for the exercise of coercive diplomacy.

\section{Conclusion}

Despite Park's efforts in implementing Trustpolitik, the South Korean leader's efforts were hampered by a range of factors. Though, Park's Trustpolitik enabled resuming reunions of families separated by the Korean War in February 2014, inter-Korean relations remained uncertain due to North Korea's continued nuclear and missile programmes, and Kim Jong Un's unwillingness to offer concessions on these issues posed a continuing challenge to PyongyangSeoul relations. Particularly interesting in this regard was Park Geun Hye's proposal for a thirdinter-Korean summit in January 2015, during which she affirmed that she did not consider North Korean denuclearisation a precondition for dialogue with Pyongyang. However, Pyongyang refused to entertain Park's proposal.

Whilst Trustpolitik has been a bold initiative in replacing Lee Myung Bak's position of hostility towards Pyongyang, it failed to yield any significant successes. Rather, mutual antagonism and suspicion between the Koreas were so deeply internalised that it was difficult to imagine Trustpolitik succeeding. The fact that Trustpolitik was a conditional form of engagement meant that the North Korean leadership had little incentive in taking Park Geun Hye at face value. Conversely, the extent of South Korean anger over Pyongyang's repeated pattern of transgressions increased in recent years due to the Cheonan sinking, the Yeongpyong Island bombardment, and the North's repeated missile and nuclear tests. Such trends amplified the lack of trust on both sides. Moreover, Park's control of her government as well as on foreign policy issues came to an end when on March 9, 2017, South Korea's Constitutional Court impeached her for a corruption scandal involving her friend, Choi Soon-sil.26 The eventual ouster of Park triggered an election which ultimately ended the Trustpolitik. While Park's removal by the

24 Kim S, "Seoul under fire for remarks on 'absorption' of North Korea," NKNews, 16 March, 2015, http://www.nknews.org/2015/03/seoul-under-fire-for-remarks-on-absorption-of-north-korea/. Accessed 31 March 2015.

25 S. Snyder, "South Korean Middle Power Diplomacy and the US Rebalance," The Diplomat, 28 March 2015 available at: http://blogs.cfr.org/asia/2015/03/24/south-korean-middle-power-diplomacy-and-the-u-s-rebalance/, accessed 31 March 2015

${ }_{26}$ Choe S. H, "Park Geun-hye, South Korea's Ousted President, Gets 24 Years in Prison," The New York Times, 6 April, 2018, https://www.nytimes.com/2018/04/06/world/asia/park-geun-hye-south-korea.html. Accessed 2 December 2019. 
Constitutional Court was a factor in disrupting Trustpolitik, the policy was by no means a panacea, given the continued impasse over North Korea's nuclear and missile ambitions.

\section{REFERENCES}

Bruce S.T, "North Korea's Six Trillion Dollar Question,” The Diplomat, 30 August, 2012, http://thediplomat.com/2012/08/30/north-koreas-six-trillion-dollar-question/. Accessed 7 October 2013.

Choe S.H, "After South Korea Spurns Park Geun-hye, She May Press Agenda Abroad," New York Times, 15 April 2016, http://www.nytimes.com/2016/04/15/world/asia/south-koreaelections-park-geun-hye.html?_r=0. Accessed 8 June 2016.

Choe S.H, "South Korea Accuses the North After Land Mines Maim Two Soldiers in DMZ," New York Times, 11 August 2015, http://www.nytimes.com/2015/08/11/world/asia/northkorea-placed-mines-that-maimed-2-south-korean-soldiers-at-dmz-seoul-says.html. Accessed 10 May 2016.

Choe S.H, "North Korea's bluster has a familiar ring. New York Times," 20 November, 2008 http://www.nytimes.com/2008/11/20/world/asia/20iht-north.4.18006513.html?_r=0.

Accessed 2 December 2014.

Choe S. H, "Park Geun-hye, South Korea's Ousted President, Gets 24 Years in Prison,", New York Times, 6 April, 2018, https://www.nytimes.com/2018/04/06/world/asia/park-geun-hyesouth-korea.html. Accessed 2 December 2019.

Delury, J, "Listening to Korea's Liberals," 38 North, 20 April, 2016, http://38north.org/2016/04/jdelury042016/. Accessed 15 May 2016. Denny, S, "The Generation Gap on Korean Unification," The Diplomat, 29 January, 2015, http://thediplomat.com/2015/01/the-generation-gap-on-korean-unification/. Accessed 28 March 2015.

Elleman M, Zagurek Jr. MJ, “THAAD: What It Can and Can’t Do,” 38 North, 10 March, 2016, http://38north.org/2016/03/thaad031016/. Accessed 8 June 2016.

Kelly R, "Yeonpyeong Shelling Summation (1): Context and Causes in hindsight," 2010, http://asiansecurityblog.wordpress.com/2010/12/13/yeonpyeong-shelling-summation-1-contextand-causes-inhindsight/. Accessed 17 June 2016. (2010) Yeonpyeong Shelling Summation (1): Context and Causes in hindsight.

http://asiansecurityblog.wordpress.com/2010/12/13/yeonpyeong-shelling-summation-1-contextand-causes-inhindsight/. Accessed 17 June 2016.

Kim S, "Seoul under fire for remarks on 'absorption' of North Korea," NKNews, 16 March, 2015, http://www.nknews.org/2015/03/seoul-under-fire-for-remarks-on-absorption-of-northkorea/. Accessed 31 March 2015.

Mehta, A, "Carter: THAAD in Korea 'Going to Happen," Defense News, 8 April, 2016, http://www.defensenews.com/story/defense/international/asia-pacific/2016/04/08/carterthaad-korea-going-happen/82803470/. Accessed 10 May 2016.

"N. Korea Warns against Factionalism in Ruling Party," Yonhap News, 26 February, 2014, http://english.yonhapnews.co.kr/northkorea/2014/02/26/73/0401000000AEN2014022600210 0315F.html. Accessed 14 March 2015.

"Obama offers change Kim Jong-Il can believe in," World Tribune, 2008, http://www.worldtribune.com/worldtribune/WTARC/2008/ea_nkorea0256_06_19.asp. Accessed 10 August 2008.

Obama B, "North Korea: An Update on Six Party Talks and Matters Related to the Resolution of the North Korean Nuclear Crisis," Hearing before the Committee on Foreign Relations, United States Senate, Washington: United States Government Printing Office, 2015. 
“Opinion Divided Over DMZ Peace Park," Korea Herald, 1 September, 2013, http://www.koreaherald.com/view.php?ud=20130901000329. Accessed 1 October 2014, Park, G. H, "Trust-Building Process and the Making of a New Korea," 2012, Park Geun Hye's personal website.

http://www.parkgeunhye.or.kr/board/mboard.asp?exec=view\&strBoardID=Lecture\&intPage $=2 \&$ intCategory $=0 \&$ strSearchCategory $=\% 7 \mathrm{Cs} \_$name $\% 7 \mathrm{Cs} \_$subject $\% 7 \mathrm{C} \&$ strSearchWord=\&i ntSeq=196760. Accessed 1 March 2014.

Park G. H, “A New Kind of Korea,” Foreign Affairs, September/October, 2011, http://www.foreignaffairs.com/articles/68136/park-geun-hye/a-new-kind-of-korea. Accessed 2 December 2012.PBS Interview with Kim Dae Jung (9 June 1998). Available at: http://www.pbs.org/newshour/bb/asia/jan-june98/kim_6-9.html, accessed 10 July 2007. "Pyongyang Threatens to End Venture," Wall Street Journal, 8 April, 2013, http://online.wsj.com/article/SB10001424127887323550604578410010892971052.html. Accessed 7 October 2013.S. Korea, U.S. begin largest-ever anti-North military drills, Yonhap News, 7 March 2016, http://english.yonhapnews.co.kr/news/2016/03/07/0200000000AEN20160307007151315.html, accessed 10 June 2016.

Seok Jin-hwan, 'President Park's Vague Plans for a 'Unification Preparatory Committee', The Hankyoreh, 26 February 2014, http://www.hani.co.kr/arti/english_edition/e_northkorea/625903.html, accessed 28 March 2015.

Seok Jin-hwan, "Park's Unification Committee's First Meeting Little More than Hot Air," The Hankyoreh, http://www.hani.co.kr/arti/english_edition/e_northkorea/650384.html, accessed 28 March 2014.

Shim, Elizabeth, "North Korea defense chief was Purged, Maybe Not Executed, Says Seoul's Spy Agency', UPI, 13 May 2015, available at: http://www.upi.com/Top_News/WorldNews/2015/05/13/North-Korea-defense-chief-was-purged-maybe-not-executed-says-Seoulsspy-agency/1931431522581/. Accessed 14 May 2015.

Sigal, Leon, "The Off-Ramp with North Korea', Nautilus Institute," 3 March 2016, http://nautilus.org/napsnet/napsnet-policy-forum/the-off-ramp-with-north-korea/. Accessed 10 May 2016.

Sigal, Leon, "What Obama Should Offer North Korea," Nautilus Institute, 3 March 2009, http://www.nautilus.org/fora/security/09017Sigal.html. Accessed 5 March 2009.

Snyder, Scott, "South Korean Middle Power Diplomacy and the US Rebalance," The Diplomat, 28 March 2015, http://blogs.cfr.org/asia/2015/03/24/south-korean-middle-powerdiplomacy-and-the-u-s-rebalance/. Accessed 31 March 2015.

Snyder, S, "U.S. Policy Toward North Korea," Council on Foreign Relations, January 2013, http://www.cfr.org/north-korea/us-policy-toward-north-korea/p29962, accessed 8 June 2016. Taylor, Gus, "Young South Koreans fear unification with North would create economic burden", Washington Times, 10 April 2013, http://www.washingtontimes.com/news/2013/apr/10/young-south-koreans-fear-unificationwith-north-wo/?page=all, accessed 28 March 2015.

"Unification committee launched," Korea Joongang Ilbo, 16 July 2014, http://koreajoongangdaily.joins.com/news/article/article.aspx?aid=2992086, accessed 28 March 2015.

Van Oosterhout, J, "Discarding Kaesong: Reviving the Cold War on the Korean Peninsula?", Foreign Policy Journal, 24 February 2016, http://www.foreignpolicyjournal.com/2016/02/24/discarding-kaesong-reviving-the-cold-waron-the-korean-peninsula/, accessed 11 May 2016. 